\title{
Contentious Politics and Participatory Democracy in Brazil
}

Brian Wampler

\section{Abstract}

Contentious politics helps individuals and groups with limited political voice to place their ideas and interests on the political agenda. Contentious politics were long thought to occur when politically marginalized group had no other means to advance their political agenda. The June 2013 social mobilization in Brazil caught most political observers by surprise, especially given the creation of a large, wide-spread participatory architecture (national conferences, councils, participatory budgeting). The innovative institutions emerging in Brazil created a policy environment in which millions of citizens have regular access to state policymaking bodies. How does the institutionalization of a broader network of participatory institutions make it easier for citizens to engage in contentious politics? In what ways does this institutionalization make it more difficult for some citizens to engage in contentious politics? In what ways has the vast network of participatory institutions been largely irrelevant to how citizens use contentious politics? This article explore how the institutionalization of an extensive participatory democracy system in Brazil alters the incentive structures that encourage citizens to engage in contentious collective action.

Keywords: Participatory Democracy. Protesto. Contentious politics. June 2013. Brazil

"Collective action becomes contentious when it is used by people who lack regular access to institutions, who act in the name of new or unaccepted claims,

and who behave in ways that fundamentally challenge others or authorities"

(Tarrow, Power in Movement: 3. Italics added).

\section{Introduction}

The wide-spread use of contentious politics in Brazil in June 2013 revealed wide-spread dissatisfaction with the policy and political environment. The

I Professor do Department of Political Science da Boise State University. Email: bwampler@boisestate.edu. 
protests caught political observers, politicians, and civil society activists by surprise given the success that Brazil seemed to be enjoying on multiple levels. Over the past twenty years, Brazil had become the darling of participationistas, deliberative democrats, development experts, the World Bank, and Wall Street. The currency stabilization of the 1990s and the return to broad growth made Brazil a center-piece of the BRICs, a positive story for Wall Street analysts, and the envy of many developing world countries. Bolsa Familia, a conditional cash transfer program, attracted considerable attention because the program appears to have helped reduce extreme poverty while also securing the policy goals of increasing immunization rates and school attendance (SUGIYAMA, 2012). Participatory Budgeting, public policy management councils, and national policy conferences received the attention of the international left, academics, and progressive sectors inside development banks (SANTOS 2005; GOLDFRANK, 2012). The innovative institutions emerging in Brazil created a policy environment in which millions of citizens have regular access to state policymaking bodies.

My contribution in this article is to explore how the institutionalization of an extensive participatory democracy system in Brazil alters the incentive structures that encourage citizens to engage in contentious collective action. "Changes in political opportunities and constraints create the most important incentives for initiating new phases of contention." (Tarrow, Power in Movement: 7). A review of contention cycles, reveals that Brazil experienced a national cycle from the mid-1970s to the early 1990s. Within the social movements that utilized contentious collective action, there was a specific focus on using participatory democracy to expand the terrain of representative democracy. This leads us to today's conundrum: After twenty years of the institutionalization of participatory democracy venues, which provide citizens with regular access to political institutions, we now see the wide-spread use of contentious politics.

In this article, I address three questions. First, how does the institutionalization of a broader network of participatory institutions make it easier for citizens to engage in contentious politics? In what ways does this institutionalization make it more difficult for some citizens to engage in contentious politics? Finally, in what ways has the vast network of participatory institutions been largely irrelevant to how citizens use contentious politics? The purpose of this article is to advance our understanding of the extensive 
institutionalization of participatory democracy affect citizens' ability to engage in contentious politics. Of course, party politics, the actions of public agents (e.g., police officers), social conflict also affect citizens' use of contentious politics. I recognize these additional influences but I narrow the analytical focus to an examination of the incentive structure created by the creation of an extensive new participatory architecture.

Contentious politics refers to civil society organizations' (CSOs) use of disruptive political practices that punctuate everyday life to draw their fellow citizens' and government officials' attention to pressing demands (TARROW, 1998; ROBERTS, 1998; TILLY, 2004). Contentious politics has long been a political tool used by marginalized and low-income citizens to press their claims on public officials (TARROW, 1998; TILLY, 2004; HOLSTON, 2008). The disruptive events are used by protestors to force government officials, media outlets, and their fellow citizens to focus their attention on the worthiness of their claims (McADAM et al, 1996; ALVAREZ; ESCOBAR, 1990).

Participatory democracy draws citizens and their organizations into deliberative, incremental policy-making processes, which are often jointly controlled by citizens and government officials. Citizens exercise voice and vote inside of state-sanctioned forums in the hopes of changing how public officials exercise public authority and allocate scarce public resources. Participatory democracy in Brazil involved concerted effort to incorporate poor citizens into incremental policy-making processes. The high level of interest in participatory democracy is due to a wide range of positive social, political, and policy effects produced, as evidenced by improvements in the quality of the public deliberation and state performance, the ability of citizens to exercise new political rights to claim social rights, and the distribution of scarce public resources to address pressing social needs (ABERS, 2000; AVRITZER, 2002; BAIOCCHI, 2005; CORNWALL \& COELHO, 2007; GIBSON \& WOOLCOCK, 2008; GOLDFRANK, 2007; LABONNE \& CHASE, 2009; MARQUETTI, 2003; SANTOS, 2005; SHAH, 2007; WAMPLER, 2007; PATEMAN, 2012).

\section{Participatory democracy and contentious politics}

This section begins with two examples of contentious politics that occurred long before the major protests of June 2013. They examples illustrate the 
multiple uses of contentious politics - They are an attempt to strengthen the 'bonds of solidarity' among activists (ALEXANDER, 2006); to provide new information to bystanders; and to gather the attention of government officials. Participatory democracy, in both cases, was co-mingled with the process of organizing contentious politics and served as the basis of demand-making.

\section{Recife, 1999}

On January 21, 1999, a community group in the city of Recife in the strategically located Entra Pulsa neighborhood led a protest to draw attention to the mayor's unwillingness to fund projects that had been selected through two different participatory programs: PREZEIS (Low-income special development zones) and Participatory Budgeting. Community activists organized a rally that first shut down traffic leading into Recife's main shopping mall just prior to lunch rush. Protestors then worked into a main traffic artery, halting traffic during the commute. The protestors were attempting to draw political and media attention to the incumbent mayor's unwillingness to dedicate sufficient resources to pay for public projects selected via participatory institutions. The mayor had agreed to fund these projects as part of an electoral agreement in which leading and influential CSOs supported his candidacy. Contentious politics were used to get the attention of the mayor.

In response to the protest, the mayor hosted a meeting to discuss policy making and participatory governance. Roughly fifteen community leaders attended the meeting (I was present as well). Their demands centered on the mayor's commitment to implement projects selected by citizens through these co-governance institutions. When the mayor protested that resources were limited, civil society leaders provided up-to-date budgetary information showing that policies selected via co-governance institutions were extremely under-funded in comparison to comparable areas of public spending. Civil society leaders demanded that participatory programs' projects be funded at the same rate that other programs were funded. The mayor, seemingly surprised at the level budgetary analysis provided by the CSOs, partially conceded the civil society leaders' argument and agreed to fund the programs at the same rate if his staff's budgetary analysis produced the same outcomes as those presented by the civil society activists. 
Crucially, civil society activists used contentious politics to secure access to key decision-makers inside the state - regular access had been provided to participatory institutions but the incumbent mayor was largely ignoring these venues. Thus, to defend participatory governance and the 1988 Constitution, activists moved outside of formal institutions to gain the attention of the mayor by using contentious politics. This example stands in stark opposition to Tarrow's central claim that contentious politics is more likely when regular access to political institutions is not available. These citizens had regular access to political institutions but their ongoing political problems were caused by the ineffectiveness of the institutions and the state's weak capacity. Building a vast democratic architecture in Brazil now calls key parts of Tarrow's argument into question.

\section{Belo Horizonte, 2004}

At a public hearing held in the city of Belo Horizonte, Brazil in March 2004, citizens lined up to address their fellow citizens as well as the government officials responsible for the city's award-winning participatory budgeting program. In this Participatory Budgeting programs, citizens enjoy the legal authority to exercise voice in a new public arena. However, there is little to suggest on this evening that government officials sitting at the official table at the head of the room are listening to speakers' demands. A forceful speaker on this particular evening is a Catholic priest, who, after not being listened to, returned to his community to organize a public protest to draw attention to the community's claim that the municipal government was not respecting their voice or vote.

The priest organized a demonstration that involved high school students carrying a coffin labeled "Participatory Budgeting." They paraded throughout their community, a shantytown located on the edge of a major avenue. The parade ended outside the favela, at the end of the shantytown. At this point, the community leaders called the mayor's office, demanding a meeting with the mayor so that their main concerns could be addressed. The mayor's staff agreed to the meeting on the condition that the protestors not close down the avenue (which was just months prior to an important municipal election). The protestors shut down the avenue for 1 minute for the purpose of generating solidarity within their group as well as to show the mayor that they had the ability to snarl traffic. 
In the subsequent meetings with the mayor and his staff, the mayor agreed to begin work immediately on several of the projects that had been won through participatory budgeting. Thus, this community thus first exercised voice and vote in a participatory venue. The government's inaction led them to engage in a disruptive public protest. This eventually the community group back into local government offices as the mayor's office agreed to implement the public works the community had previously 'won' through the participatory budgeting program.

This was a dramatic victory for the activists, who were able to secure their basic projects. Citizens used contentious politics to force the government to implement public works projects previously selected via participatory budgeting. At first glance, it appears that this was leading to higher levels of accountability and the strengthening of participatory institutions in the government's decision-making processes. However, the effects are not entirely beneficial because the government sidestepped existing implementation procedures to rush through the implementation of this particular community's projects. The government, to avoid political embarrassment, changed the process through which public works are approved for implementation. This had a negative effect on efforts to consolidate participatory governance because the government did not follow the standard set of rules, but responded to the demands of contentious politics.

This example illustrates a contradictory aspect of the interaction between contentious politics and participatory democracy: Citizens used contentious politics to get the government to pay attention to their already agreed upon demands but the government's response effectively undermined efforts to further strengthen and institutionalize the decision-making procedures that support the participatory institution. Therefore, democratic state-building via participatory democracy was undermined when citizens used contentious politics to focus on the specific projects rather than strengthening and institutionalizing democratic decision-making processes.

In sum, these two examples illuminate that contentious politics continues to exist in a parallel fashion to the routinization of participatory politics that now takes place inside of state institutions. The next section explores the role of democratic state-building to better explain how the Brazil's political opportunity incentive structure was altered. 


\section{Democratic state-building}

Participatory institutions, adopted by local governments across Latin America in the 1980s, 1990s, and 2000s, are part of a larger democratic state-building effort designed to overcome perceived deficiencies with representative democracy, including passive voters with low information, the lack of accountability among elected officials, a limited public sphere, and misallocations of scarce public resources (AVRITZER, 2002; STEPAN, 1989; CASTEÑEDA, 1993; CARVALHO, 1993; O’DONNELL, 1994; FUNG and WRIGHT, 2003; WAMPLER, 2007; BARCZAK, 2001; PATEMAN, 1970, 2012). Participatory institutions enhance the quality of democracy and improve basic service delivery of public goods to those groups historically excluded from all but the most minimal levels of state resources. The establishment of participatory democracy is best conceptualized as a new moment of democratic state building, whereby these intermediary bodies are established that further decentralize where, when, and by whom binding decisions are made.

Citizens and civil society organizations, as the political opportunity literature on social movements has shown, modify their strategies in response to changes in the social, political or institutional environment (McADAM; McCARTHY; ZALD, 1996). "Differences in patterns of state building produced differences in the opportunity structures of social movements... Tocqueville's underlying message was that state building creates an opportunity structure for collective action of which ordinary people take advantage" (TARROW,1998: 55-56). The obvious lesson for us is that the establishment of an extensive network of participatory institutions now alters the opportunity structure for engagement.

Democratic state-building is often accompanied by the use of contentious politics as ordinary citizens use disruptive, direct action to ensure that their fellow citizens and public officials hear their demands. Politically marginalized citizens have long used contentious politics to expand their rights, gain the attention of public officials and their fellow citizens, and access scarce public resources. For example, the long, drawn-out democratization of Western Europe from the $17^{\text {th }}$ to 20 th centuries included substantial use of contentious politics, thereby allowing ordinary citizens with limited access to formal democratic institutions to pressure government leaders and their fellow citizens to support the extension of rights and universal suffrage 
(TARROW, 1998; TILLY, 2004; THOMPSON, 1996; MCADAM; TARROW; TILLY, 2001; RUESCHEMEYER; STEPHENS; STEPHENS, 1992; MARSHALL, 1950). During recent transition to and establishment of democratic regimes during the 1980s, 1990s, and 2000s, extensive use of contentious politics allowed new political coalitions to develop, pushed new leaders into the centers of political power, and highlighted the ability of outside groups to successfully promote significant institutional reform (YASHAR, 2004; BAIOCCHI, 2005; GRINDLE, 2000; RUBIN, 2003; WAMPLER; AVRITZER, 2004). Three cases come to mind: South Korea, the Philippines, and Brazil all experienced the wide-spread mobilization of citizens and the renewal of civil society during the transition to democratic rule from authoritarian rule. All three countries now have extensive systems of direct citizen engagement.

Democratic state-building through participatory institutions is not uniform across Latin America or within each country due to the fragmentation of local and national states' capacity, the diversity of rules that guide participatory institutions, the repertories of strategies available to CSOs, and elected officials' interests (GOLDFRANK, 2007; MIGDAL, 2001; SCOTT, 1998; VAN COTT, 2008; WAMPLER; AVRITZER, 2004; WAMPLER, 2007; YASHAR, 2008). The establishment of participatory governance is now transforming when, where, and how contentious politics can be used, thereby encouraging us to modify Tarrow's definition of how contentious politics develop. "Collective action becomes contentious when it is used by people who lack regular access to institutions, who act in the name of new or unaccepted claims, and who behave in ways that fundamentally challenge others or authorities" (TARROW, 1998: 3. Italics added). Participatory institutions now provide regular access to large numbers of Brazilians, but they continue to use contentious politics as part of their repertory of political engagement. This suggests that regular access to participatory institutions alters the political opportunities available to citizens.

Brazil's current democratic regime induces to civil society leaders to play multiple formal and informal roles, acting as legislative aides, campaign workers, service delivery providers, party activists, elected representatives in participatory institutions, and community organizers. The boundaries between these roles are fluid, which means that in some venues community leaders represent the state, in other venues they represent a political party, 
while in others they represent the interests of their community organizations or social movements. There is a blurring of the interests CSO leaders purportedly represent in any given venue, which is why it is vital to study cogovernance venues as one institutional process embedded in broader economic and political contexts. Within democratic regimes, especially when there are competitive local elections, the cooperation of CSOs and public officials is widespread, making it necessary to conceptualize contentious politics as one political tool in a broader repertoire of political strategies employed by CSOs as they pursue their political, policy, and organizing goals. Democratic state building through co-governance institutionalizes new venues in which citizens and government officials interact, negotiate, and (sometimes) make binding policy decisions. Citizens and CSOs use these new public venues to promote their interests, but they do not limit themselves to only engaging in participatory governance. In a similar fashion, government officials will support and advocate on behalf of co-governance when their policy, governing, and political interests are aligned with citizens working within the institution.

\section{I Brazil's Participatory Democracy}

Brazilian CSOs actively engaged in contentious politics throughout the 1970s and 1980s during the drawn-out transition to democracy from military authoritarian rule (STEPAN, 1989; CASTENEEDA, 1993; KECK, 1992; ALVAREZ, 1991). A key demand of CSOs throughout the country was the direct incorporation of citizens directly into policy-making venues (AVRITZER, 2002; JACOBI, 1989; SOARES, 1998). The 1988 Constitution represents a remarkable change because it permits the direct incorporation of citizens into policy-making venues, through such mechanisms as the petition and referendum process, issue-oriented councils (conselhos) as well as local democratic experiments (e.g. Mayor in the Neighborhood, Participatory Budgeting, Future City) (SOARES, 1998; AVRITZER, 2002; VILLAS BOAS; TELLES, 1995).

In Brazil, the three most common participatory institutions include the widely established public policy management councils (conselhos), policy conferences (conferencias), and participatory budgeting (orçamento participativo). There are now at least 65,000 municipal-level councils, with hundreds of thousands citizens elected to exercise authority in these councils (Barretto 2011). Participatory Budgeting continues to be a policymaking and 
democratic tool used by one quarter of medium-sized and large municipalities. Presidents Lula and Dilma invested heavily in the national conference system, inducing more than 6 million people to participate over the past decade.

Table I - Types of participatory institutions in Brazil

\begin{tabular}{llllll}
\hline & Numbers & Participants & Voice & Vote & Key authority \\
\hline $\begin{array}{l}\text { Participatory } \\
\text { Budgeting }\end{array}$ & $\begin{array}{l}\text { 100+ mid- } \\
\text { sized and large } \\
\text { municipalities }\end{array}$ & $\begin{array}{l}\text { Hundreds of } \\
\text { thousands } \\
\text { citizens engaged }\end{array}$ & Yes & Yes & $\begin{array}{l}\text { Focus on public } \\
\text { works }\end{array}$ \\
\hline $\begin{array}{l}\text { Public Policy } \\
\text { Management } \\
\text { Councils }\end{array}$ & $\begin{array}{l}\text { 65,000 councils } \\
\text { Hundreds of } \\
\text { thousands } \\
\text { citizens elected to } \\
\text { office }\end{array}$ & Yes & Yes & $\begin{array}{l}\text { Monitor } \\
\text { government } \\
\text { programs }\end{array}$ \\
\hline $\begin{array}{l}\text { National } \\
\text { conferences }\end{array}$ & $\begin{array}{l}74 \text { conferences } \\
\text { since } 2002\end{array}$ & $\begin{array}{l}6 \text { million over } \\
\text { past decade }\end{array}$ & yes & $\begin{array}{l}\text { Proad } \\
\text { topics }\end{array}$ & Propose general \\
policy guidelines
\end{tabular}

The conselhos have their roots in the health care movement of São Paulo, which first organized during the 1970s to demand public provision of health care services to millions of the city's residents who lacked access (JACOBI, 1989). The Health Care Movement in Sâo Paulo expanded their demands to insist that citizens have the right to be involved in public policymaking. This movement and the resulting conselhos demonstrate how direct contestation by CSOs can lead to innovative practices within the state. ${ }^{2}$ Although there has been the broad proliferation of conselhos, there is limited evidence that demonstrates the impact of these institutions on policy outputs (CORNWALL and COELHO, 2007; TATAGIBA, 2002; TATAGIBA; DAGNINO, 2007). Tatagiba carried out a major review of the relevant scholarly literature and found that most analysts report that the conselhos are hampered by the severe

2 Conselhos function at municipal, state, and federal levels of government in diverse policy areas such as health care, education, children and adolescents, women, and the environment. Typically, they draw their membership from three groups: Half of the members represent "civil society," one quarter represent state bureaucrats (generally unionized employees), and another quarter represent the executive branch (mayor, governor or president). The federal government now requires that municipalities have functioning health care and education councils in place as a condition for the federal government to transfer resources to the municipality. Conselhos directly incorporate interested citizens into a format that often focuses on establishing the government's policy priorities in that particular policy arena. 
lack of capacity among the participants, including government officials and CSOs (TATAGIBA, 2002). The conselhos are thus broadly institutionalized, but they transferred limited authority to citizens.

The better known but less widely adopted participatory budgeting is not required by the federal government but is initiated at the behest of municipal governments and CSOs (GOLDFRANK, 2007; FEDOZZI, 2001; WAMPLER, 2007). In this program, citizens are incorporated into a series of meetings in which they exercise voice and vote, leading the local state to implement specific public works or social services (ABERS, 2000; BAIOCCHI, 2005; AVRITZER, 2002). Participation is based on the individual, but the rules are generally written to ensure that low-income neighborhoods receive higher per capita spending than upper-income neighborhoods. Thus, individuals representing low-income groups and communities have stronger incentives to participate. This mode of participatory policy-making gained traction in Brazilian municipalities during the 1990s as municipal governments sought to overcome basic deficiencies with the local policy-making processes. A commonly cited draw back to the participatory budgeting programs is that they focus almost exclusively on local issues. There is a disconnect between what municipal governments can accomplished and the breadth of citizens' political demands.

Finally, national policy conferences were first used in the 1940s as a means to construct a health care system that would help Brazil's industrialization. Between 1940 and 2002, less than a dozen conferences were used by Presidents to focus attention on specific policy issues. The use of conferences accelerated rapidly under Presidents Lula (2003-2010) and Dilma (20112014). National conferences are conceptualized and organized by the Federal government as a means to alter state-society relations. Participation begins at the municipal-level, where citizens participate in deliberative sessions in which they proposed new policies or comments from policies selected by the federal government. Citizens are elected to represent their respective cities at the state-level. The process is repeated. This filtering process eventually produces a policy document that is provided to the President of Brazil.

This brief overview demonstrates that that Brazil has made significant advances in the creation and institutionalization of a complex group of participatory venues. Hundreds of thousands of volunteers are now elected to 
state-sanctioned participatory venues, which represents a significant change in basic state-society relations. Over the past two decades, there has been considerable attention paid by researchers to how citizens engage and use these institutions.

\section{June, 2013}

The June 2013 protests caught most observers by surprise. There are several key features that differentiates the June 2013 from previous periods. First, the protests did not have a clearly defined leadership. Although the June 2013 protests were sparked by political brutality against the "zero bus fare" coalition, this group was one among CSOs vying to claim support. Second, the protests quickly spread across the country and were held in small and mid-sized cities, many of which had never experienced broad demonstrations. Third, the protests were multi-class. It is possible to organize these groups into three broad categories: (a) The conservative middle classes, which focused on government corruption (especially the PT); (b) progressive middle class, which focused on priorities of spending, human rights and police brutality, and the quality of public goods, such as transportation, public security, and environmental issues; (c) the new lower middle class, which focused on the quality of health care, education, and police brutality. The diffuse nature of the leadership and the multi-class participation meant that it was very difficult for activists and ordinary participation sustain participation as well as to direct their participation to achieve a clearly defined set of outcomes. Since millions of people now have "regular access to institutions," why were the protests so extensive? The next section helps explores how participatory democracy alters the incentive structure for individuals to use contentious politics to advance their agenda.

\subsection{Participatory democracy encourages contentious politics}

The principal way that PD encourages the use of contentious politics is through the empowerment of citizens; PD acts as a "School of Democracy" (BAIOCCHI, 2005). The ongoing deliberative formats of PD bring "participatory publics" into these state-sanctioned bodies, thus creating a political environment that allows citizens deliberate in public forums (AVRITZER, 2002; WAMPLER; AVRITZER, 2004). Citizens develop the skills and knowledge to promote collective action based on rights, social justice, 
and democratic deliberation. These "schools of democracy" and "participatory publics," working inside the state, help to educate, inform, and empower citizens. This draws attention to the fact that participatory democracy is not reducible to specific materials gain but includes a shift in the internal political efficacy of the participants. Therefore participatory further develops citizens' ability to make demands on the state, which creates a latent power that can be mobilized at different moments. The June 2013 protests are an excellent example of how the ongoing processes of education, empowerment, and citizenship-building can lead some groups to engage in contentious politics. Social Movements and CSOs, such as the Housing movement and the MST, work inside of democratic policymaking institutions (councils; conferences; public hearings) as well as independently of these institutions. Their work inside of the institutions provides the means to sustain their movements because they are renewing key "bonds of solidarity." Thus, the new democratic architectures provides an infrastructure that allows the most politically independent or radical actors to build the support to engage in contentious politics (WAMPLER, 2015).

Second, participatory democracy processes often involve extensive formal and informal deliberation. This allows citizens to refine their political and policy-oriented critiques of current government activities. An increase in information allows activists to better calibrate their message to link their demands to specific policy initiatives. Political slogans such as "Justice for all," or "No child should go to bed hungry," are transformed into specific policy proposals (Wampler 2012). There is, of course, the real danger that a policyoriented, technocratic approach will stifle the vibrancy of a social movement. After all, many participatory meetings are quite tedious and boring. However, the focus on public policy allows activists to draw attention to the disconnect between formal constitutional rights and the everyday experiences of ordinary people. By identifying which level of government is responsible for ensuring that constitutional guarantees are met, protestors are better able to identify specific government actions that could be changed to resolve the situation. Thus, technocratic nature of debate has the potential to expand contentious politics because citizens are able to draw attention to the failure of government officials to enforce basic rights and constitutional guarantees.

Third, participatory democracy encourages contentious politics is through the promotion of dense social and political networks. In Tarrow's 
work, having dense networks is cited as a necessary condition to promote sustained deliberations. The formal institutionalization of participatory venues decreases the communication and organizational costs associated with social movement activity; state-sanctioned participatory bodies produce or help maintain ties among civil society activists. Activists engage each other in formal deliberative sessions; they develop personal connections during informal interactions, which generate greater "bonds of solidarity" (Alexander 2006). The participatory venues reinforce "bonds of solidarity" among activists, allowing them to keep their broader political movement active during periods of more limited participation. Community leaders need to be able to mobilize citizens to attend key events or political moments associated with participatory democracy. Community leaders often need to arrange for bus transportation, child care, and basic food snacks to ease the burden on ordinary citizens as they participate. In addition to the basic organization skills, these community leaders are able to maintain social and political networks that they could mobilize to engage in direct, contentious politics. Participatory democracy allows citizens to demonstrate to government officials and their fellow citizens the strength of their mobilization efforts, their ability to reach out to others and the moral legitimacy of their demands.

During the deliberative sessions, citizens construct narratives regarding why their particular project(s) deserves funding. Citizens directly engage their fellow citizens, without media or politicians' filters. Citizens force government officials to treat them as equals, as rights-bearing members of the polity, which disrupts the normal flow of socializing in Brazil in which low-income individuals are invisible in public venues. These institutions provide citizens the opportunity to defend their interests inside the state Their mobilization and participation efforts are designed to ensure that their voices are heard and their votes counted. This politics is contentious in the sense that disrupts the common representation of favelados; and yet, it is also controlled and constrained because it occurs within the co-governance institutional framework.

Finally, poorly functioning participatory institutions encourage the use of contentious politics because there is a fundamental disconnect between citizens' expectations and institutional performance. When citizens' demands or policy preferences are not met, it creates the opportunity for citizens to 
mobilize around a specific set of demands. This is obviously tied to "Schools of Democracy" as discussed above. Poorly performing participatory provide activists with an immediate set of concerns that they can leverage to organize in protest against governments and state agencies.

In sum, participatory institutions act as "schools of democracy," allow for new forms of deliberation inside democratic institutions, and provide for the development of social networks. It is the combination of these three factors that generates a latent power that can be mobilized and used to promote contentious politics. In the case of June 2013 protests, a reoccurring theme was the poor quality of public goods provided by government. Two reoccurring themes were the low quality of the national health care (SUS) and the public education system. The evidence from Participatory Budgeting programs shows that the vast majority of participants are poor and lowermiddle class residents, the very groups that rely heavily on public goods provisions. If we conceptualize $\mathrm{PB}$ and the council system as being core nodes in a broader process of building social and political networks, we can then assert that participatory democracy encouraged the June 2013 protests because these institutions helped to build the necessary organizational support that supported the protest movements.

\subsection{Participatory democracy discourages contentious politics}

Participatory democracy depends on the close working relationship between citizens and government officials; PD complement representative democracy but, in most cases, it is officials elected through representative democracy that establish the parameters of the authority exercised by citizens. Citizens' authority is limited by the extent to which they are able work closely with government officials. As a result of being in a dependent position, citizens are less likely to use contentious politics because they don't want to disrupt their relationship with government officials. Thus, repertoires of contentious politics are delegitimized by the presence of the very institutions of participatory governance that CSOs initially demanded to expand democratic rule.

Participatory democracy also discourages the use of contentious politics as activists are habituated to work within incremental policymaking processes. CSO leaders must dedicate considerable time and energy to working on the nuts and bolts of policy. It is the patient, methodological, detailed oriented 
leader who excels under PD arrangements. These leaders are thus habituated to work through formal, incremental policy processes. The effect is two-fold. On the one hand, community associations may be controlled by those leaders who are willing to focus on the nitty-gritty world of policy change. This is an obviously important task but this set of skills is distinct from the skills needed to urge citizens to engage in contentious politics. In addition, community leaders who have spent years attempting to secure public works may be less willing to promote the use of contentious politics because they don't want to jeopardize the implementation of their public works.

Finally, participatory democracy discourages contentious politics due to the interaction between participatory democracy and representative democracy. My premise is that participatory democracy complements representative democracy, but that it is the elected officials inside of representative democracy who set the parameters for the degree of authority that will be delegated to citizens. When citizen-participants are closely aligned with government officials and when there is an election, it becomes much less likely that the citizens would engage in political activities that might discredit the incumbent government. When governments face extremely competitive elections, they place intense pressure on their civil society allies not to use contentious politics because of the potential damage that it could do to the party's image and electoral chances. CSOs are encouraged to engage in participatory governance but they are discouraged from taking steps and actions in the broader political arena that might highlight the government's incomplete support for co-governance. The weight of representative democracy and of maintaining control of the local state are more important than efforts to ensure that participatory democracy plays a vital role in a city's policy-making apparatus. A comment by an activist from Sáo Paulo in 2004 best illustrates this point as she stated, "Look, we think that PB [participatory budgeting] is the best thing that has happened to us. We can participate. We are learning how to do this. But we must reelect Marta [Mayor Suplicy]. There are many other programs that we would lose if she loses."3

Thus, participatory democracy complements democracy, but it remains in a secondary position. Citizens do have some authority and power granted

3 Interview with PB Delegate Fatima from Capella de Soccoro, November II, 2003. 
to them, but their ability to use this authority continues to remain contingent on positive, close working relationships among citizens and public officials. This has the effect of really limiting where and how citizens are able to use contentious politics. With regard to the June 2013 protests, some organizations may not have been able to assume a broader leadership role because they had deeper political ties to incumbent governments, especially the PT at the national level. The protests diminished significantly prior to the start of the Confederations' Cup, which may be attributable to the national government's efforts to claim that the continuation of the protests would hurt Brazil's international image and credibility. Many protestors, especially those individuals who are actively involved in participatory institutions, are constrained their multi-tier linkages to participatory and representative democracy institutions.

\section{Participatory democracy is largely irrelevant to current round of protests}

Participatory democracy has been institutionalized at multiple levels of Brazil's Federal state. Millions of people participate in state-sanctioned venues each year. Although there is a proliferation of venues and participants, the vast majority of Brazilian citizens has minimal, if any, contact with these venues. Millions of people have participated in these venues over the past decades and hundreds of thousands have been formally elected to positions were they are able to exercise state-authority. But, Brazil is a country of 200 million residents so direct participation is less than $10 \%$ of the adult population. Thus, the vast majority of Brazilian citizens did not have "regular access to institutions," which helps to explain why they engaged in contentious politics.

The "free bus fare" movement is often credited with sparking the June 2013 movement in the city of Sao Paulo. An analysis of the Tarifa-zero.org website shows very few mentions of councils and conferences as political strategy to address public issue. There are political writings and agenda that indicate that movement leaders sought to connect to government officials in the mayor's office as well as hold public hearings in the municipal legislature (CMV). Following the June 2013 protests, there was an increased demand for the creation of a municipal council for transportation in Sao Paulo. The lack 
of attention to the new participatory institutions suggests that more radical, younger movements initially develop political strategy that are not strongly influenced by the formal participatory architecture built in the country.

Evidence from Participatory Budgeting programs and national conferences demonstrates that the majority of participants are older than 45 years of age (WAMPLER, 2007, 2015; BAIOCCHI, 2005). This ageing population fought for the establishment of participatory politics as part of the 1980s redemocratization process. This generation was socialized to use participatory processes. In addition, similar to other countries, it is an older population that carries the weight of routine civic engagement, especially incremental policymaking.

Thus, there is now a disconnect between an older activist generation for whom, participatory democracy was a radical democratic project and a younger generation that are more likely to see it as an incremental policymaking process. Younger activists have not been drawn into the participatory structures, I argue, due to the relatively stable democratic regime (1985-present) and the incremental nature of PD. Thus, it appears to younger citizens and activists have not been habituated into incremental policymaking processes associated with Brazil's participatory democracy, which means to explain that this group didn't have the "regular access to institution" (TARROW, 1998).

The national policy conferences used by Presidents Lula and Dilma to promote better state-society dialogues are the broadest participatory innovations of the past decade. These are institutions that are managed in a top-down fashion, as a means to given citizens voice in the policymaking process. The top-down building process of these new institutional designs is quite distinct from the bottom-up innovations of the 1980s, which led to participatory budgeting and the public policy management councils. An important aspect of the national conference system is that citizens voting power is quite limited, which means that people are engaged in basic feedback and consultation loops. These institutional structures would thus not attract activists who want to produce broader changes or go dramatically beyond the policy directives of the current government.

The use of contentious politics also ties back into Brazil's significant economic transformation over the past 15 years, which transformed basic 
class structures. The progressive, liberal middle class students and activists that initiated and then sustained the protests were addressing broader political issues that are not easily contained with the current participatory venues. A common critique of participatory democracy in Brazil is that it takes "Think Globally, Act Locally" to an extreme. In this case, the progressive activists needed to think and act globally in order to move the current ruling government to expand its policy agendas.

The conservative middle class has shown little interest in engaging in participatory politics. For example $\mathrm{PB}$ has a pro-poor bias that provides few material benefits for the middle class and public management councils (i.e., health care councils) focus on public goods that are not utilized by the middle class. The conservative middle classes didn't mobilize against the military dictatorship and they also were involved in expanding the boundaries of Brazil's new democratic regime. These groups, however, did protest extensively in June 2013. Corruption was a key issue that galvanized members of the traditional middle class to participate. For more than a decade, a center-left political party has governed the country. There have been several corruption scandals that involved key leaders of the Workers' Party.

The role of the new middle class is the most perplexing. The lower middle class has dramatically increased in size over the past decade, but they don't necessarily have political parties representing their interests, a clear set of venues to express their interests, or civil society organizations advocating on their behalf. They don't have the political or policy connections to work closely with the government. The economic boom created this large lower middle class, but the innovative mix of representative and participatory institutions have been unable to meet their needs. Economic growth and an expansion of educational opportunities has greatly increased their "capabilities" (a la Sen) but the country's principal political institutions have not provided the venues to incorporate their interests.

In sum, this section focused on how participatory democracy both encourages and discourages contentious politics as well as how participatory democracy is largely irrelevant to the creating the incentives that lead people to engage in contentious politics. Participatory democracy has been widely extended across Brazil but most people are not involved; the vast majority of Brazilians are not aware that there are numerous opportunities for them to participate in public life. Furthermore, the most radical groups, such as 
the Black Blocs, are not likely to engage in participatory institutions because participatory institutions are incremental policymaking venues. More radical groups, such as the Black Blocs, are more likely to demand broader and more immediate changes than the incremental institutions allow for.

\section{Concluding remarks}

Participatory democracy provides Brazilian citizens, as well as their peers across Latin America, unprecedented regular access to formal policymaking institutions. The establishment of these new institutional processes alters how and where citizens CSOs employ contentious politics, which have long been used by politically marginalized populations to draw the attention of their fellow citizens and public officials to their demands. This article helps us to better conceptualize how participatory institutions change the incentive structures for social movements and CSOs as they consider using contentious politics.

Researchers must first contend with the possibility that the wide-spread institutionalization of participatory democracy had little to no bearing on the use of contentious politics. By this, I mean that these institutions were largely irrelevant to changing the opportunity structures that induced people to engage in participatory politics. The most radical groups who are likely to use the most disruptive forms of contentious politics are also the least likely to participate in the incremental policy-making. Middle class conservatives who don't rely on the state for education, health, transportation, or public security, are not likely to engage in the new participatory system. The new $\mathrm{C}$ class in Brazil are interested in improving the quality of public goods, but there is not a clear causal link between the existence of participatory institutions and overall improvements in the quality of public goods provision. In sum, one of the most important lessons is that the vast participatory architecture of Brazil may have had little to no impact on citizens' decisions to participate in the June 2013 protests. Thus, the citizens had the formal opportunity to have "regular access" to participatory institutions but they chose not to be involved.

The formal institutionalization of participatory processes discourages citizens to use disruptive politics outside of officially sanctioned participatory venues. If citizens choose to use contentious politics "in the streets," there is an increased risk that government officials' will be less likely to work with them 
within participatory institutions. Government officials attempt to undermine citizens' political claims to the use of contentious politics by asserting that when citizens move outside formal institutional mechanisms they are no longer playing by the democratic rules of the game. Ironically, then, the presence of participatory governance can provide the rational for governments to assert that citizens should not be using contentious politics and that they should be working within state institutions. Although citizens can and do obviously contest these assertions, it is harder for CSOs to justify the use of disruptive politics due to the formal presence of institutions specifically designed to give citizens to regular access to decision-making bodies.

Finally, in this article, I demonstrate that participatory democracy encourages the use of contentious politics by fostering "Schools of Democracy" inside these new venues, by drawing Participatory Publics into these new venues, by promoting formal and informal deliberative exchanges, and generating denser associational networks. The nation-wide protests in Brazil were thus partially encouraged by the institutionalization of a broad participatory system. Gramsci's focus on political culture is particularly relevant because the analytical framework developed in this article illuminates how political culture and political organizing were altered over the past twenty years in response to building a broad, participatory democratic system. Citizens and CSOs now have a much wider range of access points into the state, which changes the incentive structure that conditions their choice of political strategies.

Major protest cycles, such as June 2013, are more likely when a confluence of events brings three numerically large groups into the streets: the progressive middle class, the conservative middle class and the new lower middle classes. Based on the analytical logic of this article, we should expect large protests against the national-level PT to be rare events because the progressive middle classes and the organized sectors of the lower middle classes have their interests intertwined with the PT. The direct incorporation of millions of Brazilians into participatory democratic institutions decreases the likelihood that contentious politics will be actively used because activists are careful to ensure that they have reasonably good relationships with executives (presidential administration, governors, mayors). Thus, if we conceptualize participatory institutions as "schools of democracy," there is currently the development of 
an activist base that is more likely to be mobilized to use contentious politics when the national government is no longer controlled by the PT. As long as PT remains in power at the national level, we should expect smaller and more limited use of contentious politics because many of the most vocal activists are not likely to take to the streets.

The June 2013 depended on the mobilization of two groups that don't normally use contentious politics: Conservative groups and lower-middle class citizens, many of whom are not closely tied to CSO. Conservative groups may come out in force but we should expect their participation to be much more infrequent as these groups invest more heavily in representative democracy. As lower-middle class groups become more established, both economically and politically, we should expect that these groups will become more involved in formal political institutions, which include both party politics and participatory institutions. Thus, the wide-spread use of contentious politics will continue to be uncommon events.

\section{Bibliography}

ABERS, R. 2000. Inventing Local Democracy: grassroots politics in Brazil. Boulder: Lynne Reinner Publishers.

ALEXANDER, J. C. 2006. The Civil Sphere. New York: Oxford University Press.

ALVAREZ, S. E. 1990. Engendering Democracy in Brazil: Women in Transition Politics. Princeton: Princeton University Press.

AVRITZER, L. 2002. Democracy and the Public Space in Latin America. Princeton: Princeton University Press.

BAIOCCHI, G. 2005. Militants and Citizens: the politics of participatory democracy in Porto Alegre. Stanford: Stanford University Press.

BARCZAK, M. 2001. Representation by Consultation? The Rise of Direct Democracy in Latin America. Latin American Politics and Society. 43(3): 37-59.

CASTENEEDA, J. 1993. Utopia Unarmed. New York: Vintage Books.

CARVALHO, J. M. 1987. Os Bestializados: o Rio de Janeiro e a República que náo foi. Sáo Paulo: Companhia das Letras.

CORNWAll, A.; COElHO, V. S. 2007. Spaces for Change? The Politics of Citizen Participation in New Democratic Arenas. London: Zed Books. 
DAGNinO, E. 2008. Challenges to Participation, Citizenship and Democracy: Perverse Confluence and Displacement of Meanings. In: BEBBINGTON, A. J.; HICKEY, S.. MITLIN, D. C. (eds.). Can NGOs Make a Difference? The Challenge of Development Alternatives. London: Verso.

1998. The Cultural Politics of Citizenship, Democracy and the State. In Sonia E. Alvarez, Evelina Dagnino, and Arturo Escobar, eds., Cultures of Politics/Politics of Cultures: re-visioning Latin American social movements. Boulder: Westview Press.

DAGNinO, E.; TATAGIBA, L. 2007. Democracia, Sociedade Civil e Participaçáo. Chapeco: Argos Editora Universitaria.

FEDOZZI, L. 1998. Orçamento Participativo: reflexóes sobre a experiência de Porto Alegre. Porto Alegre: Tomo Editorial.

FUNG, A.; WRIGHT, E. O. 2003. Deepening Democracy: institutional innovations in Empowered Participatory governance. New York: Verso.

GIBSON, C.; WOOLCOCK, M. 2008. Empowerment, Deliberative Development, and LocalLevel Politics in Indonesia: Participatory Projects as a Source of Countervailing Power. Studies in Comparative International Development. 42(2): 151-180.

GOLDFRANK, B. 2007. The Politics of Deepening Local Democracy: Decentralization, Party Institutionalization, and Participation. Comparative Politics, 39 (January 2007):147-68.

GRINDLE, M. 2000. Audacious reforms: institutional invention and democracy in Latin America. Balitmore, MD: Johns Hopkins University Press.

JACOBI, P. 1989. Movimentos Sociais e Políticas Públicas: demands por saneamento básico e saúde. Sáo Paulo, 1974-84. Sáo Paulo: Cortez Editora.

KECK, M. E. 1992. The Workers' Party and Democratization in Brazil. New Haven: Yale University Press.

LABONNE, J.; CHASE, R. S. 2009. "Who is at the Wheel When Communities Drive Development? Evidence from the Philippines." World Development. 37(1): 219-231.

MAINWARING, S. 1999. Rethinking Party Systems in the Third Wave of Democratization. Stanford: Stanford University Press.

MARQUETTI, A. 2003. Democracia, Equidade e Effciencia, o Caso do Orçamento Participativo em Porto Alegre. In: AVRITZER, L.; NAVARRO,Z. (Eds.), A Inovaçáo Democrática no Brasil: o Orçamento Participativo. Sáo Paulo: Cortez Editores. 
MARSHALL, T. H. 1950. Citizenship and Social Class. Cambridge: Cambridge University Press. MCADAM, D.; MCCARTHY, J. D.; ZALD, M. N. 1996. Comparative Perspectives on Social Movements: political opportunities, mobilizing structures, and cultural framings. New York: Cambridge University Press.

MCADAM, D.; TARROW, S.; TILLY, C. 1996. To Map Contentious Politics. Mobilization 1:14-28.

MCADAM, D.; TARROW, S.; TILLY, C. 2001. Dynamics of Contention. New York: Cambridge University Press.

MIGDAL, J. S. 2001. State in Society: Studying How States and Societies Transform and Constitute One Another. Cambridge: Cambridge University Press.

NAVARRO, Z. 2003. O "Orçamento Participativo" de Porto Alegre (1989-2002): Um conciso comentário crítico. In: AVRITZER, L.; NAVARRO,Z. (Eds.), A Inovaçáa Democratica no Brasil. Sáo Paulo: Cortez.

NYLEN, W. R. 2002. "Testing the Empowerment Thesis: The Participatory Budget in Belo Horizonte and Betim, Brazil." Comparative Politics 34:127-145.

2003. Participatory Democracy versus Elitist Democracy: lessons from Brasil. New York: Palgrave Macmillian.

O’DONNELL, G. 1994. “The State, Democratization and Some Conceptual Problems: A Latin American View with Glances at Some Post-Communist Countries." SMITH, W. C.; ACUMA, C. H; GAMARRA, E. A. (eds)., Democracy, Markets, and Structural Reform in Latin America. New Brunswick, Conn.: Transaction Publishers.

PATEMAN, C. 1970. Participation and Democratic Theory. Cambridge: Cambridge University Press.

2012. "Participatory Democracy Revisited". Perspectives on Politics. 10 (01): 7-20.

ROBERTS, K. 1998. Deepening Democracy? The Modern Left and Social Movements in Chile and Peru. Stanford: Stanford University Press.

RUBIN, J. W. 2003. "Meanings and Mobilizations: A Cultural Politics Approach to Social Movements and States." Latin American Research Review. 39(3): 106-142.

RUESCHEMEYER, D.; STEPHENS, E. H.; STEPHENS. J. D. 1992. Capitalist Development and Democracy. Chicago: University of Chicago Press. 
SANTOS, B. de S., ed. 2005. Democratizing Democracy: Beyond the Liberal Democractic Canon. New York: Verso.

SCOTT, J. C. 1998. Seeing Like a State: How Certain Schemes to Improve the Human Condition Have Failed. New Haven: Yale University Press.

SHAH, A. 2007. Participatory Budgeting. Washington, D.C.: World Bank.

SOARES, J. A. 1998. Os Desafios de Gestão Municipal Democrática: Recife. Recife: Centro Josué de Castro.

STEPAN, A. 1989. Democratizing Brazil: problems of transition and consolidation. New York: Oxford University Press.

TATAGIBA, L. 2002. Os conselhos gestores e a democratização das políticas públicas no Brasil. DANIGNO, E. (ed.)., Sociedade Civil e Espaços Públicos no Brasil. São Paulo: Paz e Terra.

TARROW, S. 1998. Power in Movement: Social Movements and Contentious Politics, $2^{\text {nd }}$ edition. New York: Cambridge University Press.

TOUCHTON, M.; WAMPLER, B. unpublished article. "Contracting, Contesting, and Co-optation: Social Movement Strategies under New Institutional Arrangements in Brazil.

THOMPSON, E. P. 1996. The Making of the English Working Class. New York: Vintage Press. TILLY, Charles. 2004. Contention and Democracy in Europe, 1650-2000. New York: Cambridge University Press.

VAN COTT, D. L. 2008. Radical Democracay in the Andes. Cambridge: Cambridge University Press.

VILlAS BOAS, R., TELLES, V. 1995. Poder Local, Participaçáo Popular, Construçáo da Cidadania. São Paulo: Instituto Pólis.

WAMPLER, B.; AVRITZER, L. 2004. Participatory Publics: Civil Society and New Institutions in Democratic Brazil. Comparative Politics 36: 291-312.

2007. Participatory Budgeting in Brazil: contestation, cooperation, and accountability. 2007. University Park, PA: Pennsylvania State University Press.

. 2008. "When does participatory democracy deepen democracy? Lessons from Brazil."

Comparative Politics. 41(1): 61-82.

2015. Activating Democracy in Brazil: Popular Participation, Social Justice, and Interlocking Institutions. University of Norte Dame Press. 
YASHAR, D. J. 2005. Contesting Citizenship in Latin America: the rise of indigenous movements and the postliberal challenge. Cambridge: Cambridge University Press.

Recebido em 10.08.2014

Aprovado em 17.12.2014

\section{Protesto, mobilização social e democracia participativa no Brasil}

\section{Resumo}

Este artigo explora como a institucionalização de um amplo sistema de democracia participativa no Brasil altera os incentivos que encorajaram os cidadãos a se envolver nos protestos de Junho de 2013. Protestos e mobilização política ajudam os indivíduos e grupos politicamente marginalizados a colocar suas ideias e interesses na agenda política e na esfera pública. O uso de protestos já foi pensado, por especialistas como Tarrow, como alternativa nos casos em que grupos marginalizados não têm acesso às instituições políticas. Os protestos de Junho de 2013 no Brasil pegaram a maioria dos observadores políticos de surpresa, especialmente tendo em conta a existência de uma ampla arquitetura participativa no país (conferências nacionais, conselhos, orçamento participativo). As instituições inovadoras emergentes no Brasil criaram um ambiente político em que milhões de cidadãos têm acesso regular aos órgãos políticos do Estado. Como a institucionalização da democracia participativa criou novas oportunidades para que cidadãos usassem os protestos? De que forma esta institucionalização tornou-os mais difíceis? Finalmente, até que ponto as instituições participativas foram irrelevantes para gerar os protestos?

Palavras-chave: Democracia participativa. Protestos. Junho de 2013. Brasil 